\title{
Technological Innovation Audit: an Effective Way to Manage Information Asymmetry in Technological Innovation
}

\author{
Yiyang Fan \\ Business School, University of Shanghai for Science and Technology \\ 516 Jun Gong Road, Shanghai 200093, China \\ Tel: 86-136-1176-7830 E-mail: fyyqq@usst.edu.cn \\ Jianming Hou \\ Business School, University of Shanghai for Science and Technology \\ 516 Jun Gong Road, Shanghai 200093, China \\ Tel: 86-021-5527-2873 E-mail: houjianming@usst.edu.cn
}

$\begin{array}{lc}\text { Received: January 5, } 2012 & \text { Accepted: February 10,2012 Published: March 1, } 2012 \\ \text { doi:10.5430/bmr.v1n1p147 } & \text { URL: http://dx.doi.org/10.5430/bmr.v1n1p147 }\end{array}$

\begin{abstract}
The paper analyzes the role of different stakeholders and their principal-agent relationship in technological innovation management system. It also examines the information asymmetry that faces the stakeholders in the system and the adverse consequences generated by the particular circumstance. Technological innovation audit can serve as a solution to the information asymmetry in technological innovation management, the importance of which is discussed from the perspectives of different stakeholders in the paper.
\end{abstract}

Keywords: Technological innovation audit, Information asymmetry, Technology innovation management

\section{The proposal of the problem}

In 1970s, American economists carried research on market transactions based on information theory, leading to the proposal of asymmetric information theory "analyzing markets with asymmetric information." Asymmetric information in the management originated from accountability, which refers to the fiduciary relationship between principals and agents.

The principal-agent relationship in technology innovation management can be defined from three aspects: technological innovation employees and managers, managers and shareholders, corporate and external stakeholders. Commissioned by managers, employees from technology, sales and production departments provide human, material and intellectual resources in order to achieve labor transactions by receiving payment. Managers employed by shareholders manage the company within their given authority and get paid. Additionally, corporate keeps a principal and agent relationship with external stakeholders including financial institutions, government, supply chain partners, and consumers. Layers of stakeholders in technological innovation management are shown in Figure1.

In technology innovation management process, information asymmetry exists between employees and managers, investors and managers, corporate and external stakeholders. For instance, the technological staff might know more about the technological innovation progress and what kind of investment needed for their designated projects compared to their managers whose major way to keep up with the progress is to analyze the results of projects and to evaluate the employee performance. Therefore, information asymmetry emerges as the information superiority resides in the technological staff while the mangers can only accept the implementation information of technological innovation in a passive way or achieve the efficiency of technological innovation projects by providing some incentives.

Similarly, information asymmetry exists between the principals and the trustees on other levels of technological innovation activities, which complicates the process of technological innovation management and leads to moral hazards and adverse selection problems.

The problem with current technology innovation management studies is that they introduce relevant management 
techniques, determine the progress of technological innovation, and evaluate technological innovation competence from a systematic and networking perspective that lacks analysis of specific stakeholders in technological innovation activities. Therefore, analyzing information asymmetry in technological innovation activities is important in coordinating the relationship among stakeholders in technological innovation activities, improving the corporate cohesion, enhancing the efficiency of technological innovation, and promoting the corporate development.

\section{Asymmetric information and the analysis of adverse factors in technology innovation management}

\subsection{Asymmetric information and adverse selection between managers and employees}

According to agency Exhibit 1, technological innovation employees carry out innovation activities commissioned by managers who establish standards and work plans based on past experience and use material or spiritual rewards to encourage employees to work harder. But working in high positions, managers might not know as much about the problems hindering the working process as those who participate in the technological innovation projects. Information asymmetry occurs to managers in every aspect of innovation activities such as when deciding whether R\&D personnel are designing experiments in accordance with the wishes of the enterprise, whether they are seeking personal profits by exploiting job convenience, or if they are avoiding reporting relevant issues occurring to the innovation activities. It can also be difficult for managers to know how capable production personnel are to tackle demanding tasks or how well they are implementing those tasks according to the work plans. Additionally, other issues such as whether sales staff are obeying the enterprise rules when selling products or whether they are building their personal interests upon business interests, whether technological innovation staff are honest about their past credit records, can all appear as information disadvantage for managers.

Adverse selection and moral hazards between innovation employees and managers in the principal-agent relationship can be reflected in the following areas: those employees who neither carry out work according to the enterprise's technological standards and work plans nor have little sense of responsibility in completing their job tasks; those who choose not to communicate with managers to work out problems but rather fabricate experiment statistics and work performance when faced with difficulties during innovation activities; and those who leak important statistics or technological secrets to seek personal interests.

\subsection{Asymmetric information and adverse selection between managers and shareholders}

As shown in Figure 1, managers who are commissioned by shareholders are in charge of business management including technology innovation activities and get paid. Shareholders enjoy ownership of the company's property and major decision-making rights such as buying and transferring shares, the amount of which is proportionate to the amount of shares they possess. But the rights of shareholders do not include approving technological innovation projects. Although technological innovation is becoming increasingly significant in affecting the prosperity of enterprises, shareholders command a lot less knowledge than manages about what is fundamental to the successful technological innovation, just as how managers know less about innovation details than working staff does. Information asymmetry between shareholders and managers can be manifest in many ways. Are managers as competent and well-informed about their competitors as to manage technological innovation projects? Do they have good work ethics to deal with conflicts or to keep business secrets when they change to another job? With a few general shareholders' meetings in a year, shareholders can hardly acquire sufficient information about working process or come up with effective strategies.

Adverse selection and moral hazards between shareholders and managers impede shareholders' interests when managers choose projects that yield immediate profits instead of those that benefit the enterprise in a long-term, or when they fail to choose employees whose professional competence best fits the need of their work, or when they violate professional ethics to forge corporate performance trading for expense records for personal interests.

\subsection{Asymmetric information and adverse selection between corporate and external stakeholders}

The external stakeholders in technological innovation (Figure1) include suppliers and consumers, as well as government that provides supervision and management, venture capital firms that invests, and financial institutions that provides funds. One type of information asymmetry exists between the enterprise and stakeholders in the supply chain. The novelty and uncertainty of technological innovative products might bring huge market risks to stakeholders because the demand of the market itself - that is constantly changing - is difficult to predict. Another reason is that lack of precise criteria for evaluating the maturity of the products might cause the enterprise's R\&D products to fail to reach the standards required by the market. Additionally, consumers and the enterprise may also encounter information asymmetry. Consumers are the representative of the market and their recognition of the products decides whether the technological innovation will be accepted by the market. However, some business and technology innovators can only predict users' needs by using their judgments and personal experience without applying investigative market research to consumer 
analysis. Similarly, most consumers can only acquire information and make judgments about the products based on advertisements' description or the creditworthiness of the enterprise, but know little about the technological innovation components or whether they need the products as proclaimed by the advertisements. The third type of information asymmetry exists between the enterprise and its creditors. Government, venture capital firms and financial institutions evaluate enterprises' performance based on prior assessment reports, expecting for the success of technological innovation and recovery of funds. But they might not have enough time to verify the truthiness of the reports and therefore get taken advantage by some companies who provide incomplete information about technological innovation or even fabricate statistics exaggerating the budget for their own purposes.

Information asymmetry between corporate and external stakeholders can lead to two types of adverse selection and moral hazards. In order to maximize its profits, some companies hold back the real situation of the technological innovation products and harm the interests of stakeholders in the supply chain, including suppliers, competitors and consumers. Another adverse selection and moral hazard arise from enterprises and investors, including government who provide financial support, venture capitalists, and financial institutions. For example, some companies defraud their investors of fund for technological innovation projects through fabricated, or select technological innovation projects that are not conducive to long-term development only to pay off the debt within the given time.

\subsection{Asymmetric information and adverse selection on the departmental level within corporate}

Although the senior management of the enterprise regularly evaluate the performance and arrange training in management on all levels, they still encounter information asymmetry when deciding whether lower-level management carry out work in an independent, scientific and equitable way, or whether the reports of successful technological innovation are all truthful and accurate.

Asymmetric information among management on all level causes the subordinate management to adjust management methods and procedures to their own advantage. For example, if senior management ask subordinate management to implement performance assessment, the subordinate departments might make arbitrary changes in the standards for assessment to their own end, which accounts for the adverse selection of fair performance assessment. As a result, the adverse selection conducted by the subordinate management increases moral hazards in the particular departments. These hazardous behaviors might bring some immediate benefits, but will damage the profits of the enterprise, and ultimately the departments and individuals who make the adverse selection - in a long term.

In conclusion, adverse selection and moral hazards brought about by the information asymmetry between principals and agents can severely impair the efficiency of technological innovation and affect the long-term development of enterprises as well as the public interests.

\section{Analysis of the role of technological innovation audit in improving asymmetric information in technological innovation management}

\subsection{Technological innovation audit}

The causes of information asymmetry in technological innovation system are that the needs of different stakeholders are not balanced, and the results of the evaluation are not objective. For instance, most SMEs (small and medium enterprises) lack funds, scientific and technological talents and the sagacity for innovation capacity in technological innovation. And because of these difficulties, SMEs usually need external funds, such as bank loans, government funds, and venture capital, to support them when they carry out technological innovation projects. These external funders require identification of the technological innovation capability, evaluation of technological innovation performance, and the supervision of technological innovation activities, which should be provided by an institution that is free from the enterprise stakeholders. In technological innovation audit, external auditors - the independent third party - give audit reports in accordance with open standards, evaluate the fairness, truthfulness and reliability of technological innovation activities, and provide suggestion to improve and regulate the performance of enterprises. Therefore, technological innovation audit brings balance to the needs of different stakeholders and adds more objectivity to the evaluation results.

\subsection{Information theory in explaining demand for technological innovation audit}

The concept of technological innovation audit originated from the traditional audit that aims at reducing agency costs as a result of a common demand of principals and agents. The purpose of technological innovation audit is to improve the effectiveness of technological innovation capacity in evaluating technological innovation projects. The theoretical background of why technological innovation audit is important lies in two aspects - Signaling Theory and Information System Theory.

Signaling Theory states that information asymmetry can be reduced when an entity passes a signal to another entity. The 
theory hypothesizes that in technological innovation participants of innovation activities have more information than investors and users of innovation activities. If the investors and users do not know about the specific innovation effects, they will provide funds or purchase products with the average market price. This will lead to two possible scenarios: when the technological innovation project is more difficult to carry out than expected, the technological innovation participants will experience opportunity cost; if the technological innovation project is less challenging as expected, then the innovation participants will obtain opportunity gain. The withdrawal from the market or the exaggeration of business performance arising from the above respective scenarios is called adverse selection.

Information System Theory focuses on the applicability of technological innovation capability and performance evaluation in technological innovation system. The hypothesis of the theory is that different stakeholders rely on technological innovation capability and performance evaluation to make decisions like capital investment made by investors or potential investors and adjustment of industrial structure made by government. Therefore, it is important that the information concerning technological innovation audit is credible and valid in decision-making process.

\subsection{The application of technological innovation audit}

Technological innovation audit provides an integrated management of technological innovation, which is illustrated by Fraunhofer Society, a German research organization. Fraunhofer Society carried out applied research on the audit of enterprises' technological innovation capability in different fields, including innovation process, innovation strategy, innovation structure, and innovation culture. According to a study conducted by Bullinger in 2007, the vulnerability of SMEs in technological innovation is the lack of sagacity for innovation talents and capacity, weak professional and technical ability and production incapability, which distract SMEs from taking initiatives in technological innovation. Reports provided by external audits can help develop a deeper understanding of enterprises' potential for improvement, thus leading to effective innovation strategies and action. Through the effective management of technological innovation audit, German SMEs improved their sales by $13.5 \%$ on average and by $55.8 \%$ at the greatest. Additionally, Richard C. M (2004) conducted technological innovation audit survey on 213 enterprises in Beijing, China, studying the difference of innovation capability among these enterprises, which also suggests the importance of technological innovation audit.

\section{The structure of technological innovation audit}

As a new field in management audit, technological innovation audit broadens the scope of traditional financial audit and extends its use to supervise, guide, and evaluate enterprises' technological innovation activities. The application of technological innovation audit can not only increase the success rate of technological innovation activities, but also enhance enterprises' recognition and correction ability in this regard.

Categorized by the characteristics of information asymmetry in technological innovation management, the structure of technological innovation audit can be divided into three aspects (Table 1):

- Information asymmetry between employees and managers can be solved through the audit of the professional and technological innovation ability of staff and the incentive mechanism.

- Information asymmetry between shareholders and creditors can be solved through the audit of enterprises' credit database and technological and technological innovation projects.

- Information asymmetry between enterprises and external stakeholders can be solved through the audit of adaptation of technological innovation projects in the market.

\section{Conclusion}

In a world that is working by the rules of market economy, the information asymmetry in the process of technological innovation is inevitable and the emergence of technological innovation audit is the result of economic and social development led by scientific and technological progress. According to the information theories in technological innovation audit and some European countries' experience in applied research, technological innovation audit can provide different stakeholders of technological innovation with more objective, fair, professional and systematic services regarding science and technology.

\section{References}

Carey. (2000). Voluntary Demand for Internal and External Audiniting by Family Business. Auditing, 19,57-64.

Davide Chiaroni, Vittorio Chiesa, Federico Frattini. (2011). The Open Innovation Journey: How firms dynamically implement the emerging innovation management paradigm. Technovation, 31(1): 34-43. http://dx.doi.org/10.1016/j.technovation.2009.08.007

Hans-jorg Bullinger, Fokus innovation. (2007). Beijing: Science Press (Chapter2-3). 
Kathryn Cormican, David O'Sullivan. (2004). Auditing best practice for effective product innovation management. Technovation, 24(10): 819-829. http://dx.doi.org/10.1016/S0166-4972(03)00013-0

London R, Rosenberg, N. ( 1986). The Positive Sum Strategy. Washington. C. National academy Press.

Miao Qihu, Chen Jie, Wang Fanghua. (2006). Analysis of technologicali nnovation financing based on a symmetric information theory. Studies in Science of Science, 2, 130-134.

Richard C. M. Yam, Jian Cheng Guan, Kit Fai Pun, Esther P. Y. Tang. (2004). An audit of technological innovation capabilities in chinese firms: some empirical findings in Beijing. Research Policy, 33(8): 1123-1140. http://dx.doi.org/10.1016/j.respol.2004.05.004

Tim Edwards. (2002). Innovation and organizational change: developments towards an interactive process perspective. Technology Analysis and Strategic Management, 12 (4), 445-464. http://dx.doi.org/10.1080/713698496

Vittorio. Chiesa, Paul. Coughlan, and Chris.A.Voss. (1996). Development of a Technical Innovation Audit. Journal of Product Innovation Management, 13, 105 -136.

Table 1. The structure of the audit of technological innovation

\begin{tabular}{|c|c|c|}
\hline $\begin{array}{l}\text { Categories of information } \\
\text { asymmetry }\end{array}$ & $\begin{array}{l}\text { The structure of technological } \\
\text { innovation audit }\end{array}$ & $\begin{array}{c}\text { The content of technological innovation } \\
\text { audit }\end{array}$ \\
\hline $\begin{array}{l}\text { Information asymmetry } \\
\text { between employees and } \\
\text { managers }\end{array}$ & $\begin{array}{l}\text { Technological innovation } \\
\text { capability and incentive } \\
\text { assesment }\end{array}$ & $\begin{array}{l}\text { Employers' professional ability, } \\
\text { technological innovation ability, } \\
\text { management's incentive programs }\end{array}$ \\
\hline $\begin{array}{l}\text { Information asymmetry } \\
\text { between managers and } \\
\text { shareholders }\end{array}$ & $\begin{array}{l}\text { Credit database monitoring and } \\
\text { project review mechanism }\end{array}$ & $\begin{array}{l}\text { Management credit, the conformity of } \\
\text { the enterprise's technological innovation } \\
\text { ability and its corporate strategy }\end{array}$ \\
\hline $\begin{array}{l}\text { Information asymmetry } \\
\text { between enterprises and } \\
\text { external stakeholders }\end{array}$ & $\begin{array}{l}\text { The evaluation of the fitness of } \\
\text { innovation results in the } \\
\text { market }\end{array}$ & $\begin{array}{l}\text { The social responsibility of the } \\
\text { enterprise, the acceptance of innovation } \\
\text { products }\end{array}$ \\
\hline
\end{tabular}

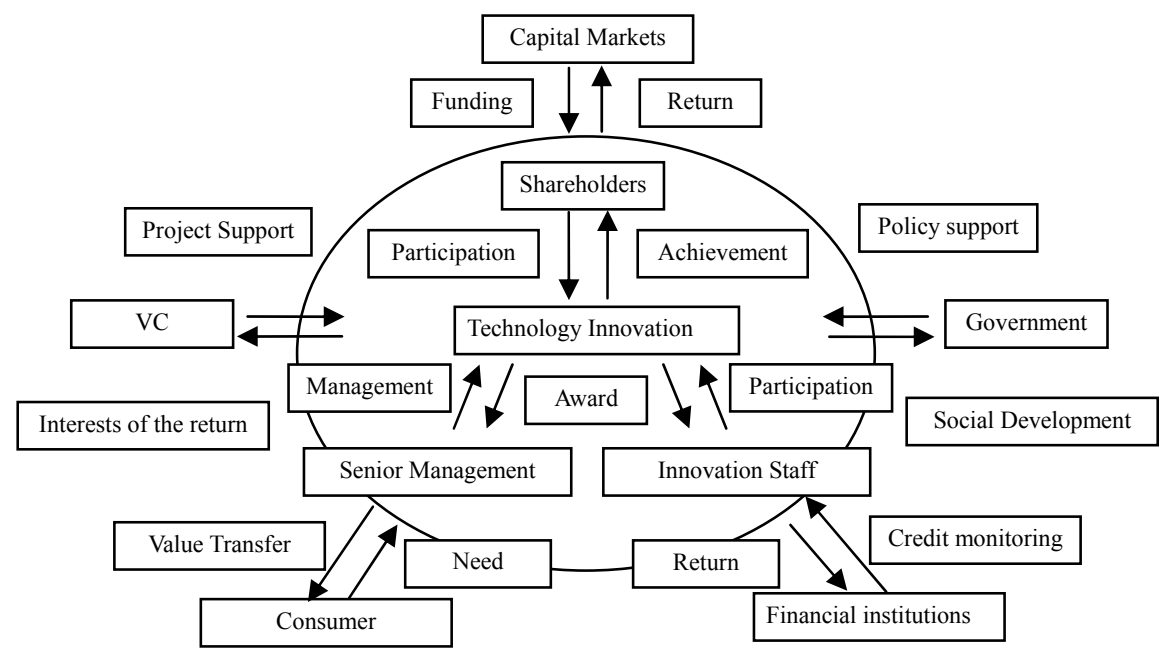

Figure 1. The layers of stakeholders in technological innovation 